\title{
DESCRIPTION OF A NEW SPECIES OF ACTINIAN OF THE GENUS EDWARDSIELLA FROM SOUTHERN CALIFORNIA.
}

\author{
By J. Playfair McMurrich, \\ Of the University of Toronto, Canada.
}

The only species belonging to the family Edwardsiidæ hitherto described from the west coast is that from Unalaska which Torrey ${ }^{1}$ has identified with the Edwardsia sipunculoides of Stimpson.

The present form differs markedly from this and is sufficiently different from other known members of the family to warrant its recognition as a distinct species, for which I propose the name Edwardsiella californica. It may be identical with a form from San Pedro mentioned, but not described nor named, by Torrey in the paper just referred to.

\section{EDWARDSIELLA CALIFORNICA, new species.}

Anaheim Bay (Creek), California: Muddy shore, about one mile inland, at or below low water, one example; mud flats and shore at, or below, low tide, "Stingaree Hole," six examples.

Type.-Cat. No. 30716, U.S.N.M.

All the examples were completely contracted so that both the capitulum and tentacles were concealed. The scapus was covered by the brown furfuraceous epidermis, characteristic of Edwardsians, and was grooved longitudinally by eight rather deep invections, marking off a similar number of broad longitudinal ridges. These latter bore large and usually prominent nematocyst capsules, which were arranged in a single row on the distal part of the scapus, but more proximally were in two or three closely adjacent rows, so that it seems proper to refer the species to the genus Edwardsiella. The physa was large and smooth; it lacked the epidermis present on the scapus, but had numerous minute particles of sand adhering to it.

Color.-In examples preserved in formalin the scapus was of a dark chestnut-brown color, due to the epidermis, and the physa was clear and transparent.

Size.-Height of column in contracted examples $2.8 \mathrm{~cm}$.; diameter of column $0.4 \mathrm{~cm}$.; length of physa about $0.3 \mathrm{~cm}$.

1 H. B. Torrey. Anemones (of the Harriman Expedition) with discussion of variation in Metridium. Proc. Washington Acad. Sci., vol. 4, 1902, p. 378. 
Structure.-A series of transverse sections showed that the number of tentacles was 16 , and that they were arranged in the typical manner with reference to the perfect mesenteries, namely, one over each directive chamber, three over each sulculolateral chamber, and two over each of the other chambers. It also possesses the typical arrangement of the mesenteries, there being in addition to the eight protocnemes a pair of rudimentary mesenteries in each protocnemic sulculolateral chamber and a single one in each lateral and sulco-lateral chamber. As is usual in the Edwardsiidæ these rudimentary mesenteries are confined to the uppermost part of the column.

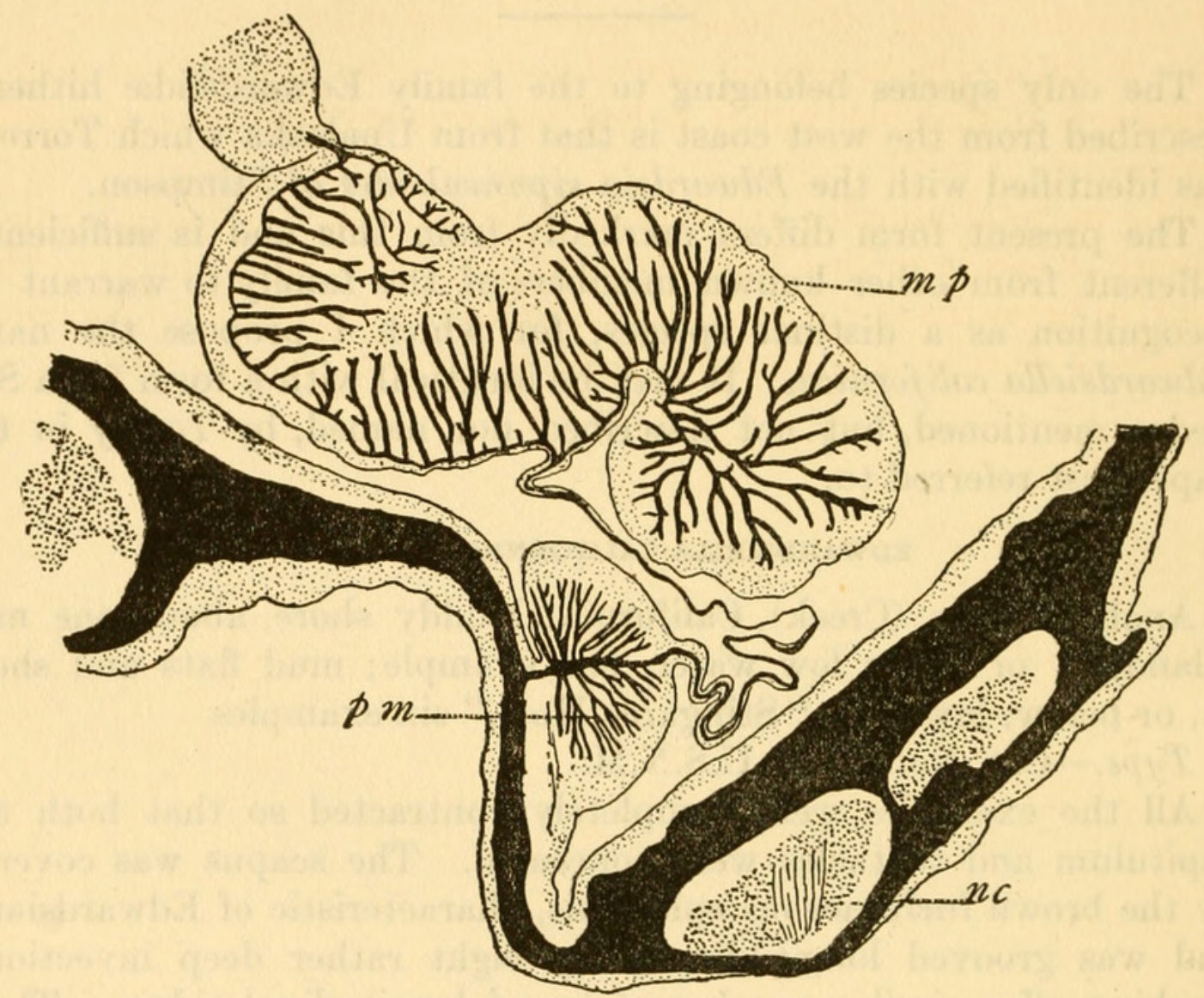

Fig. 1.-Transverse section of a protocnemic mesentery of Edwardsiella californica. $m p$, MUSCLE PENNON; $n c$, MEMATOCYST CAPSULE; $p m$, PARIETAL MUSCle.

The muscle pennons of the protocnemes have a very characteristic pattern. They resemble those of E. pudica (=E. adenensis Faurot) in that the mesenteries join them almost at the middle of their breadth (fig. 1), a condition that evidently results from the excessive development of the lateral or basal lamella of the pennon, which seems to be a direct continuation of the axial mesoglœa of the pennon and, like it, bears numerous lamellæ, which, however, are secondary branches. In E. pudica these are arranged bipinnately on the basal lamella, but in the present species, while the more proximal ones are arranged in a palisade-like manner on one side of the basal lamella, more distally the latter breaks up into a number of irregularly branching plates, so that the lateral portion of the pennon has the appear- 
ance of a rounded lobe. Throughout the portion of the pennon medial to the point of attachment of the mesentery, the lamellæ, though branching to a greater or less extent, have a palisade arrangement, gradually diminishing in height, however, to a point about midway between the attachment of the mesentery and the medial edge of the pennon, beyond which point they again rapidly increase in height; there is thus a marked separation between a medial and a more lateral group of lamellæ.

There are about 16 well developed lamellæ in the medial set and about 9 in the more lateral one, while the basal lamella bears about 14 secondary ones, the total number being, therefore, about 39 or 40. A slight thickening of the endoderm over the medial edge of pennon is noticeable, but it is less pronounced than in many other species.

The parietal muscles are very well developed, consisting of about 8 more or less branched lamellæ on either side of the main axis, their relative breadths being such as to give the cross section of the entire muscle a more or less hemispherical or rounded conical outline. 


\section{$2 \mathrm{BHL}$ Biodiversity Heritage Library}

Mcmurrich, J P. 1913. "Description of a new species of actinian of the genus Edwardsiella from southern California." Proceedings of the United States National Museum 44(1967), 551-553.

https://doi.org/10.5479/si.00963801.44-1967.551.

View This Item Online: https://www.biodiversitylibrary.org/item/53514

DOI: https://doi.org/10.5479/si.00963801.44-1967.551

Permalink: https://www.biodiversitylibrary.org/partpdf/52492

\section{Holding Institution}

Smithsonian Libraries

\section{Sponsored by}

Smithsonian

\section{Copyright \& Reuse}

Copyright Status: Public domain. The BHL considers that this work is no longer under copyright protection.

This document was created from content at the Biodiversity Heritage Library, the world's largest open access digital library for biodiversity literature and archives. Visit BHL at https://www.biodiversitylibrary.org. 